\title{
Indicators and Index for Rural Area: Case Study at Pekan Parit Raja, Johor, Malaysia
}

\author{
Nurasyikin Miskam ${ }^{1} \&$ Haryati Shafii ${ }^{2}$ \\ ${ }^{12}$ Universiti Tun Hussein Onn Malaysia
}

\begin{abstract}
The issues on developmental transformation for urban growth had already happened prior to the reign of British, after the time of liberty and up until now including to rural areas and small towns. This also included the changes in Pekan Parit Raja located in Johor that was formerly known as a small town that ran farming activities as its main source of economy due to its topography of having low land surface. However, developmental transformation for the last 20 years had affected the changes in land use when expansion of housing areas, outlet spaces, and social amenities occurred. This paper describes developmental transformation occurred in the town by observing the effects towards local communities which covers economy sector, social and environment. In the final stage of this study, the outcome obtained will be used to generate indicator of well-being for Pekan Parit Raja. The study used survey data with 367 respondents to see the perception of the residents with the developmental transformation that had happened. The outcome of the study found that changes in economic spaces have led to economic changes in the town with offer of employing opportunities and increasing rate of household income. In terms of facility services of water and electrical supply, it may be wise said that local residents were given with these facilities. This condition proved that local residents in the study area were well served with one of the basic needs in their daily lives. The outcome of the study also indicated that the level of neighborly relations between them is still remain close and firm although with the rapid occurrence of urbanization process and development. For accessibility of facilities, average of local residents had high rate of interaction with social amenities by distance less than 1 kilometer. Nevertheless, behind the changes of urbanization process, there were also changes in social in the area. Even though that the town is still can be considered as safe to settle down, yet crime scenes such as theft, burglary, and snatch regularly happen. This kind of scene will certainly affect the local residents and raising tense among them. Hence, it's impairing their well-being. On the other hand, from environmental aspect that covers air and water quality and natural disaster has yielded negative outcome to the town. This is happened due to the effects of rapid economic growth that commonly will be reflected to the environment. The changes in environment had threatened well-being of the locals and environment consistency. This explains that life well-being is threatened and needs careful consideration in development aspect. It can be concluded that this case study may be used and applied particularly to authorities and development planner as guidelines to consider well-being of local residents for every development before carrying it out. Usage of indicator in observing development towards sustainable environment will greatly ensure the well-being of the whole community

Keywords: Indicator, Rural area, Pekan Parit Raja, Well-being
\end{abstract}

\section{Introduction}

Impacts from globalization have caused change in territory spaces almost in most nations worldwide (Garret, 2000; Nyaholo, 2001, Kelles, 2005; Dreher, 2006). Metropolitan cities become the main focus in investment sector and as machinery to rapidly boost country economic growth and Malaysia was included in that process. In developing countries, rural areas and small towns also experienced development exposure (Amir, 2005).

This condition could be seen in the late of $20^{\text {th }}$ century and in early of $21^{\text {st }}$ century when restructuring process of rural areas had been done in Western Europe, North America and Israel Israel (Cloke, Goodwin \& Milbourne, 1997; Mahon, Fahy \& Cinneide, 2009; Nelson, 2001; Sofer \& Applebaum, 2006). At the same time, developmental transformation did occur in rural areas to certain countries such as China (Ahmed, 1993; Su et al., 2011), India (Dandekar, 1988), Philipine (Gibson, Cahill \& McKay, 2010) and Thailand (Ouyyanont, 2000). Malaysia was no exception from undergoing the process. Malaysia went through rapid urbanization process since 1970's and in fact became the most rapid developing country in Southern East Asia in around 1980's. This was the result of cities economic growth under policies and strategies country development in accordance with New Economy Policies.

Effects from the developmental transformation had increased the well-being of the community that moved in line with economy progress processes. However, negative impacts from development may reduce benefits that community should gain directly. In this condition, it explains that certain developments probably 
succeed at the time, but may fail the next day if people could not foresee the effects of the development. To realize the progress that supported only with profit, a development that doesn't consider well-being aspect and environment and instead straying away from the guidelines of human life necessities is in fact will bring no change neither in cities nor rural areas.

As clarified in 21 Agendas, humans deserve to have healthy lives and should obtain all basic needs in every aspect and might as well as preserving and protecting the ecosystem. By standing with the principle, every ongoing development to be carried out should consider well-being of community without neglecting each space in the time frame where the development is performed. Beginning with $8^{\text {th }}$ Malaysia Plan, level of living standard has acquired a place in Malaysia where every economic growth of the country must be followed by increasing well-being of the whole people. This kind of approach explains that every advancement evaluation not only focusing on economy sector but focused interest on human establishment. Moreover, Malaysia has hinted out its interest in developing sustainable indicator since $6^{\text {th }}$ Malaysia Plan that stated efforts must be initiated by providing bench mark or indicator to monitor and evaluate a development (A. A. Hezri, 2004).

Basically, it can be said that it is too difficult to measure well-being of a community or an individual specifically. It is not subtle that can be measured directly. There is none means or way that could cover human satisfaction to achieve maximum life well-being.

\section{Rural Transformation Development and Its Relation with Community Life Well-Being}

According to Midgley (1995), social development is a social transformation process planned to elevate community well-being in the whole dynamic development process. Based on previous explanation, it turned out that development process and its relation with the requirement of community well-being stated the significance for a developing country. In that case, rural areas development transformation aspect is so important to observe due to processes involved have high and obvious influences to community well-being and country. In this state, it actually has made impact since centuries ago and certainly until now.

For an example, Daud (2005), explained that European countries had gone through transformation in many ways starting with industrial revolution, began at the end of $18^{\text {th }}$ century. The output of industrialism transformation was its form of economy had changed from agriculture into manufacturing that produced numerous more productive new technologies. This explains that transformation happened had altered the living way of conservative community at that time. The achievement had led the quality of life of Western community much better and more proud compared to other countries worldwide.

Rural transformation is seen to bring positive changes to society groups and rural communities (Buller \& Wright, 1990). In interpreting developmental transformation effects well-being of a country, Ibrahim (2009) concurred that the presence of economic streams had created much more employments and capable to overcome poverty issues and thus reducing migration from town to city. From the study of Huang and Zhan (2009), rural transformation in China had successfully increased household income of the population. As a result, the transformation had led the rural area residents to start personal business since 1980's, known as 'Township and village Enterprise (TVE's). In 1990, the enterprise had attracted about 92.7 million labors in rural area and increased to 135.1 million towards 1996 . With this method, migration of labor to cities was mitigated.

Segupta (2007), stated well-being and quality of life for local residents in India is increasing with proper road transportation system development. In short, transportation system development is sufficient to ease community movement or sell goods to increase income and change socioeconomic level.

Hence, it was cleared that enhancement of well- being moving with economic growth process. This is because economic growth providing job opportunities and required basic facilities. However, rapid economic growth initiates pressure to surrounding if seen from different perspective eventually. Related question arises whether the growth of the economy led to an improved standard of living or otherwise.

\section{Indicator and Index Formation for Life Well-Being}

Forming a robust development for a city requires scrutiny examination towards physical and social environment of the city. Therefore, urban environment was formed as measurement indicator in evaluating wellbeing status in a particular area. In the terms of concept and definition of well-being, it may cover wide scope of area and difficult to explain and thus measuring it will be difficult to perform. However, according to Gasper (2003), measurement for well-being without theory had existed since 1940's by economist. Generally, wellbeing needs to be measured socially and economically.

Some parties used the method of Gross Domestic Product (GDP) to see progress of quality of life (Yusof, 1999). But, A. Shahabudin et.al, (2002), explained the presence of weakness in indicator such as GDP because it only refers to economic growth only. Similar to quality of life, well-being measurement is also divided into two categories, objective and subjective. Objective measurement uses economic statistic, social and environment approach while subjective measurement refers to feeling or actual experience of someone in his or her life (McGillivray \& Clarke, 2006; Van Hoorn, 2007). Well-being measurement objectively is using variable 
such as income, expense, housing, health and education that it may be obtained from individual consumption. Subjective measurement on the other hand uses variable such as happiness and satisfaction, experienced by an individual like having stable new job, and happy family. It is easier to measure if the measurement uses perception method (Camfield \& Skeffington, 2003).

\section{The Concept of Well-Being Indicator}

Well-being is a wide concept comprises multiple elements and has many relations that make it harder to be described (Gasper 2003). According to Travers and Richardson (1993), well-being concept was seen, referring to many aspects of human life. Common aspects related to well- being are living standards, quality of life and human establishment (McGiilivray, 2007). This situation imparts many challenges in comprehending concept and definition of well-being (Langlois \& Anderson, 2002). Some with different definition will create overlapping to existing concept. Most of the researchers tend to use particular concept and will create diverse concept differently.

Issues on well-being in Malaysia particularly and developing countries generally increasingly became focus of attention. Most of earlier studies had been done in developed countries in the West. From the studies, they pointed out that indicator was vital measure in evaluating status of well-being. According to Paola Jirón \&Giulietta Fadda (1999), the word 'indicator' alone brought along up reminder, announcement, guide, description, a sign or an effect. They added, indicator is something that provides key to understand important or more complex issues where it able to clarify for a tendency or late identified phenomenon.

The term generally came from Latin word 'indicare' meaning exposing or guiding, telling in general or assessing (Hammond, 1995). Indicator is a measurement that can be used to evaluate transformation. It may explain achievement in community, either moving forward or backward, increasing or decreasing, better or plummeting or return back to initial of that particular year (Md. Noor, 2000). Therefore, it makes the indicator as an important tool in analyzing the results, outcomes and impacts in underlying any program.

Indicators of well-being not only include economic development, but it also covers social, psychological, cultural and environmental. This was concurred by Henderson (1996), Eckersley (1999) and Blair (1998), which did not support if measuring advancement for the population only through economic aspect because the process of life itself covers many other aspects of life. Nieboer et al., (2005), used goal achievement, behavior, status and comfort as an indicator of well-being. Li (2006), too in the study of wellbeing in China had used five life domains of health, family, social relationship, employment and environment. Conversely with Ahmad 2000, well-being indicator covered numerous components namely eating style, shelter, health, education, security, social stability, recreation, physical environment and surplus opinions.

Another related indicator of well-being is the level of accessibility to basic facilities is provided and enjoyed. Sharkey et al., (in Rostam et al., 2009), explained there was existence of the relationship between the needs of the community with basic accessibility of the services. Society with proper living is filled with basic needs and that cannot be achieved easily. Furthermore, the dimensions of well-being also take into consideration welfare and human friendliness in human relationship, human to nature and human to God. This is due to, according to Zakaria (2007), well-being also had closed-bonding with the value of local and religious practice of the community and practice with the religious theory or otherwise. In this context, family is the most important agent to create well-being in human relationships. So, Ali \& Abdullah (2001) had used the housing component for families, clean water supply, sewage and domestic system of waste disposal and security as an indicator of well-being.

Researchers such as Abdul Ghani (2003), Calvert et al., (2000) and Polnac et al., (2001) used factor of income, education, health, housing, transportation and communication, security and safety, family, work environment and social participation as an indicator of well-being. In Canada, the indicator used to measure the community well-being covering employment, education, financial security, family life, housing, social participation, entertainment, health, safety and environment (Human Resources and Skills Development Canada, 2011). Listed components of those were almost the same as listed in the Malaysian Quality of Life Index (MQLI).

Indicator index usage in measuring well-being was also used in other countries. For example in the Netherlands, Living Condition Index used to view and monitor the community pattern of life in an area that considered aspect of housing, health, recreational activities and ownership of personal belongings. Personal Wellbeing Index in Australia used the domain such as standard of living, health, life achievement, relationship, security, community relation, future preparation, and religious in measuring well-being of the population (Australian Centre on Quality of Life, 2006). Processing out the indicator that considers the various aspects of human life become important measurement in evaluating the well-being status of the population living in the particular area. 


\section{Malaysian Quality of Life Index (MQLI)}

Progress of a nation can be measured based on continuous quality of life improvement of its people. Evaluation of a country's development must not be focused solely on economic considerations, but also covered other aspects that describe quality of life transformation of the people. Thus, Malaysia had established Malaysian Quality of Life Index (MQLI) where a more quantitative approach is used in evaluating quality of life.

The MQLI was first calculated in 1999 when MQLI 1999 was the first report to use composite index in assessing the quality of life in Malaysia. Based on MQLI report (1999), quality of life is defined as covering self-development, healthy lifestyle, access and liberty to acquire knowledge, standard of living beyond basic needs and fulfill psychological needs to achieve comparable level of social well-being similar with the aspiration of the nation. When a society turns to a better condition of life in general, then the quality of life may assume as increased. MQLI is a composite measurement based on ten fields specifically Income and Allocation, Work Environment, Transportation and Communications, Health, Education, Housing, Environment, Family Life, Social Participation and Public Safety.

This field is considered equally significant for the well-being and quality of life. A total of 38 indicators were used in the calculation of the index which clearly showed the selected indicators to provide an aggregate measurement about the quality of life in this country for evaluating the impact of economic development towards population. According to Shafii (2010), MQLI measurement had consider many development dimensions, where each weakness done often referred to only one or some development indicators such as GDP. In the system of MQLI calculation, all indicators will be marked with positive or negative sign. Selected indicator for each component was based on the extent to which how it reflect the particular component and how further time series data is available.

\section{Community Well-Being in Pekan Parit Raja}

Well-being is related to how individuals perceive their lives whether it is satisfactory, non-satisfactory, good, bad or as such. This individual perception is based on evaluation of satisfaction experienced from past experience with wishes that had been achieved or dissatisfaction which wishes failed to be achieved. Well-being has to do with the perception that it is may explain many aspects and true condition of humans in everything they do (Frank, 1963).

Many researchers were using perception to measure well-being and quality of life. This is due to there is a notion that well-being is measured based on how a person feels satisfaction in important aspects of the life. In this context, according to Shafii (2010), whatever they satisfied with, comfortable, serene, safe, etc. by the individual based on their impression or perception opinions towards the environment had explain the well-being and quality of life in accordance with space and time. This is precise with review by Senlier et al., (2009), which defined urban quality of life as the relationship between perception and sense of the people as well as their experience in the area they live.

In this study, the status of well-being is not only relied on the structure of the Pekan Parit Raja alone, but also involved the perception of the population to changes in its environment. Thus, subjected perception is based on the experience and viewing of comfort, safety, communication and evaluation in other aspects of life.

\section{Index and Indicator To Measure Well- Being}

Rural development is a complex multidimensional concept with rural condition and trend that range which could not be described by a measurement. Furthermore, each analysis and policy for rural areas changes from time to time. To meet these diverse perspectives, a set of indicators should be established. Rural indicators must cover the whole subjected rural areas and have a deep understanding in the implementation and rural policy.

In the Pekan Parit Raja, the community status of well-being is by considering changes happened from coming in pressure of the development. By that, covered well-being not only viewing to the aspects of economic development but also involving various specific aspects that cannot be separated such as social and environmental aspects.

Indicator formation considers and includes needs of the current population. In this study that will apply the modification of existing indicators in Malaysia submitted by the Economic Planning Unit. Therefore, the basic fields selected as indicators of well-being cover physical, social and economic. Among the selected components are economic, housing, social harmony and environment. Selection factors are mutually related in influencing community well-being status in the Pekan Parit Raja as shown in Table 1. 
Table 1: Proposed Index and Indicators of Community Well-Being in the Pekan Parit Raja and modification of the Malaysian Quality of Life Index (Researcher, 2011)

\begin{tabular}{|l|l|l|}
\hline Component & \multicolumn{1}{|c|}{ Index } & \multicolumn{1}{c|}{ Indicator } \\
\hline \multirow{5}{*}{ Economic } & & Poverty rate \\
\cline { 2 - 3 } & \multirow{4}{*}{ Housing } & Home ownership \\
\cline { 2 - 3 } & & Vehicle ownership \\
\cline { 2 - 3 } & \multirow{3}{*}{ Social harmony } & Numbers of room \\
\cline { 2 - 3 } & & Electrical supply \\
\cline { 2 - 3 } & Water supply \\
\cline { 2 - 3 } & \multirow{3}{*}{ Environment } & Neighborly relation \\
\cline { 2 - 3 } & & Accessibility to facilities \\
\cline { 2 - 3 } & & Social problem \\
\hline & & Water quality \\
\cline { 2 - 3 } & Air quality \\
\cline { 2 - 3 } & Natural disaster \\
\hline
\end{tabular}

According to Table 1, refers to the selected index fields, selection of indicators to measure the wellbeing of the community in Pekan Parit Raja is by reviewing the description state of the environment conditions in the study area. Through these indicators, community well-being dimensions of economic development yield is able to be measured based on the living standard and living level enhancement from positive economic impact that occurred within 20 years. Indicators of well-being is formed by taking the data covering the period 1990 to 2010 to taking the year 2000 as the base year. The possibility local community well-being increasing or decreasing depends to field index and indicator generated from study with analysis conducted on the field.

\section{Well Being Indicator Based On Respondent Perception for Pekan Parit Raja}

Well-being indicator formation for Pekan Parit Raja community is based that the area has experiencing rapid development pressure in the last 20 years and certainly affected to well-being to some of its community somehow. Transformation occurred in the area is due to higher institution development and industrial sector that became core expansion and development in Batu Pahat district.

Pekan Parit Raja is a small town located inside industrial area and just $10.0 \mathrm{~km}$ away with Lebuh Raya Utara-Selatan. The area is assumed as strategic due to the community main road from Batu Pahat urban to Ayer Itam where it takes only 14.0 kilometer from Ayer Itam and 22.0 kilometer from Batu Pahat urban. Moreover, according to MPBP (2004), research area will be fully developed near to year 2020 where Pekan Parit Raja will be upgraded to be state Regional Semi Centre with the current scenario and future prospect. Hence, produced indicator will describe the shifting condition happened either indicate advancement or otherwise.

In MQLI calculation, all indicators will be given positive or negative sign. Selected indicator for each component is based on how far it able to explain a particular component and how far time series data is available. For an example, for positive signed indicator (like life span, literate rate) means any increasing to values that marking better condition, while negative signed indicator (like baby death rate, jobless rate) shows otherwise (Economic Planning Unit, 1999).

In this study, MQLI calculation system that refers to positive and negative markings had been applied in well-being indicator formation where data taken is based on respondent perception in Pekan Parit Raja. Table 2 shows index and indicator of community well-being analysis for Pekan Parit Raja.

According to results obtained for indicator in economy index, all of them gave positive sign. What can be explained from all three of the indicators are poverty rate, housing and vehicle ownership, results of the index and indicator for community in Pekan Parit Raja. In line with positive economic growth in duration of 20 years has proven successful income allocation among local community until capable of reducing poverty rate in that small town.

Apart from that, increasing income rate yield allows most of the residents in this small town to support family and itself as well as able to provide important needs for a family to do daily routine that is ownership of vehicle and house. House ownership of a member of the house is actually influenced by income and awareness to get quality and suitable with the cost. According to Economic Planning Unit (1999), transportation and housing are important for economic growth and well-being as well as quality of life of the people.

For the second index, housing, involved component is number of room, electrical and water supply. Outcome of the study shows the entire indicator in the index too giving the same positive response. For number of room indicator, it shows that residents in Pekan Parit Raja having awareness and considering comfort aspect of the members in the house by providing number of bed room with size of the house. Via this study, it can be explained that performance viewed for each family in Pekan Parit Raja is to try to get well-being by providing a 
minimum condition at least family members can carry their daily lives. Other than that, aspect that may support daily routine like electrical and water supply were also included in the positive condition in Pekan Parit Raja. This matter truly contributes towards better well-being.

Table 2: Analysis of Index and Indicator of Community Well-being Based on the Perception of Respondents in Pekan Parit Raja

\begin{tabular}{|c|c|c|}
\hline Component & Index & Indicator \\
\hline \multirow{12}{*}{ Well-being } & \multirow{3}{*}{ Economic } & Poverty rate $(-)$ \\
\hline & & Home ownership (+) \\
\hline & & Vehicle ownership (+) \\
\hline & \multirow{3}{*}{ Housing } & Number of room (+) \\
\hline & & Electrical supply (+) \\
\hline & & Water supply (+) \\
\hline & \multirow{3}{*}{ Social harmony } & Neighborly relation $(+)$ \\
\hline & & Accessibility to facilities (+) \\
\hline & & Social problem $(+)$ \\
\hline & \multirow{3}{*}{ Environment } & Water quality (-) \\
\hline & & Air quality (-) \\
\hline & & Natural disaster (-) \\
\hline
\end{tabular}

When viewing to social harmony index, indicator for neighborly relation and accessibility to facilities gives positive sign while indicator for social problems has indicated negative sign. What can be understood from the outcome of the conducted study, that although positive economic growth occurred, the community in the area still practicing community living way by expressing it with visits, interaction, cooperation, and as such. This kind of neighborly relation that develops solidarity from since to today is assume as decisive well-being.

Similar with accessibility of residents to basic amenities or services. Proper level of accessibility with a certain facilities in Pekan Parit Raja may indicate level of well-being and comfort for the local resident and this is in accordance with economic changes and their monthly income level. However, behind the transformation of urbanization, there is social changes happened in that area. Even though that the town is still can be considered as safe to settle down, yet crime scenes such as theft, burglary, and snatch regularly happen. This kind of scene will certainly affect the local residents and raising tense among them.

For environment index, all indicators that are water and air quality and natural disaster had given negative output in Pekan Parit Raja. This situation happened from the consequence of rapid economic growth that usually will be reflected back with the effect to environment. Among them are disposal of toxic residue into river, smoke emissions from industry, land use changes, and as such. Normally, effects of environment deterioration will give negative impact to people to continue enjoying better well-being.

Thus, it is clear here that index indicator formation may help to observe effect from development transformation towards well-being community of local resident. What can be observed that well-being of the community in Pekan Parit Raja is getting better. Although, none evident or index before this established to be compared, but from the results of the study conducted, it may see development changed had given positive impact to community in Pekan Parit Raja. Hence, all impacts gained by present generation may able to benefit the next generation. The importance is continuity sustainable development needs to be applied in urbanization by considering equality in many aspects especially environment quality and natural resources consumption.

\section{Discussion and Summary}

When the community shifts into better living situation generally, thus quality of life and well-being may be assumed have increased. The quantitative assessment for well-being in the Pekan Parit Raja is based on the collected data in the field. Community well-being indicator of Pekan Parit Raja is calculated based on four fields by using 12 indicators. All the selected fields and indicators are based on the significance and factors that related to each other.

It can be concluded that developmental transformation occurred in Pekan Parit Raja has affected to socioeconomic local community. Economic section changes has caused migration attraction either in Malaysia or from outside. This contributed into demographic transformation and economic strength in Pekan Parit Raja town. The function of this small town is also followed in transformation wave where it has become more modern with the existence of business center and services similar to that other developing.

However, in development moving in this small town, there are some impacts from developmental transformation that needs to be considered up. Decreasing environment quality may be seen from air quality and water quality of the river. Land use changes to comply development indirectly contributed to natural disaster. 
However, even air and water pollution in Pekan Parit Raja is controllable, but if this matter continues without any monitoring conducted, then there is possibility environment quality in the small town is getting worse and ability of Pekan Parit Raja to accept development will be considered as giving negative impacts. In this case, environment needs to be taken care of because it is part of meaningful human life ecosystem; destruction environment means destruction of human itself.

Therefore, it is clear that indicator index formation could assist to see the effects from developmental transformation towards well-being to the local community. Next, is the well-being of local community in Pekan Parit Raja is increasing. Even though there is no evidence or developed index before this to be compared with, but from the results of the study conducted may observe development occurred has given positive impacts towards Pekan Parit Raja local community and hence all impacts obtained by the present generation may benefit the next generation. The important is continuity sustainable development needs to be applied in urbanization by taking into account equality in many aspects especially environment quality and natural resources consumption.

\section{Conclusion}

In term of hierarchy context in Batu Pahat city, Pekan Parit Raja is now classified as Regional Territory Semi Centre after shifted as Minor Settlement Centre (1987-1998). Regional Territory Semi Center is ranked in the second after the Regional Centre. This city center hierarchy configuration refers to prospect, function and significant ran in a certain area. It also as an important element in planning work for a city or territory. Thus, it can be recognized through changes in center of residence due to economic section transformation and increasing functions offered. Presence of educational sector is among the main factor among that caused the transformation as well as industrial sector, enterprises, and services as main contributions to the transformation.

Sustainability development that occurred in the 20 years in Pekan Parit Raja is purposely to expand economy towards elevation of well-being of life to the community. Changes that entirely happened show similarity that available in other bigger cities. This is proven that the transformation for an area is vital because it will boost economic growth and socioeconomic transformation to the surrounding areas. However, in planning for the advancement, Pekan Parit Raja community should not forget its root, custom tradition and cultural. This is because, by that stand of principle, will able to remove all negative values brought with the modernizing wave.

Note: Special Thanks to ORRIC, UTHM for Short Grant Vot. C005 with title "Transformasi Pekan Parit Raja, Johor: Kajian Terhadap Kesejahteraan Hidup Masyarakat dan Persekitaran" and all perople contributed to successful my research.

\section{Reference}

[1] A. Hezri (2004). Sustainability Indicator System and Policy Processes in Malaysia: A Framework for Utilisation and Learning.

[2] Shahabuddin F. A. (2002). Index Kualiti Hidup Penduduk Daerah-Daerah di Semenanjung Malaysia dalam Mohamad, L. Z., Jemain, A. A., Hussain, M. Y.\& A. Shahabuddin, F. A. (2002). Impak Pembangunan Kualiti Hidup dan Persekitaran. Kuala Lumpur: Utusan Publications and Distribution Sdn. Bhd.

[3] Abdul Ghani, N. (2003). Kualiti Hidup Penduduk Pulau Negeri Terengganu: Satu kajian di Pulau Redang dan Pulau Perhentian. Kolej Universiti Sains dan Teknologi Malaysia. Tesis Ph.D.

[4] Ahmad, A. (2000). Ketaksamaan kesejahteraan sosial di Malaysia: suatu manifestasi pembangunan tak seimbang? Dalam Rostam, K. et al. Alam, Manusia dan Pembangunan di Malaysia. Prosiding Seminar Kebangsaan Geografi. Bangi: Universiti Kebangsaan Malaysia.

[5] Ahmed, M. U. (1993). Development of Rural Industries and Transformation of China's Rural Economy. Asia-Pacific Journal of Rural Development, 3, ms. 1-19.

[6] Ali, N. \& Abdullah, F (2001). Penunjuk kepada Kesejahteraan Isirumah dan Keluarga. Dalam A. Latiff, J. J. Pereira \& A. Hezri Adnan (2001). Lestari Abstracts: Penyelidikan Penunjuk Pembangunan Mampan di Universiti Kebangsaan Malaysia. Bangi: Institut Alam Sekitar dan Kebangsaan.

[7] Amir, A. (2005). Impak Limpahan Pembandaran Ke Atas Kampung Pinggir Bandar Di Wilayah Metropolitan. Ph.D Tesis: Universiti Teknologi Malaysia

[8] Australian Centre on Quality of Life (2006). Personal Wellbeing Index - Adult. Dicapai pada Jun 23, 2011 dari http://www.deakin.edu.au/research/acqol/ instruments/wellbeing-index/pwi-adult-english.pdf.

[9] Blair, P.J., (1998). Quality of Life and Economic Development Policy. Economic Development Review 16 (1), pp. $50-54$.

[10] Blowers A., (1993). Environmental Policy: The Quest for Sustainable Development, Urban Studies, 30(22), ms. 775-796

[11] Buller, H. \& Wright, S. (1990). Rural Development: Problems and Practices. Hants, England: Avebury.

[12] Calvert, G. \& Henderson, H. (2005). The Calvert-Henderson quality of life indicators. Dicapai pada Jun 6, 2011 dari http://www.calvert-henderson.com/.

[13] Cloke, P., Goodwin, M., \& Milbourne, P. (1997). Rural Wales: Community And Marginalization. Cardiff: University of Wales Press.

[14] Dandekar, M. N. (1988). Transformation in Agriculture And Rural Development. Journal of Rural Development (Hyderabad), 7, pp. 541-559.

[15] Daud, F. (2005). Transformasi sosial : Evolusi atau Revolusi. Kuala Lumpur: Penerbit Universiti Malaya.

[16] Dreher, A. (2006). Does Globalization Affect Growth? Evidence from A New Index Of Globalization. Applied Economics: Forthcoming.

[17] Eckersley, R., (1999). Is Life Getting Better?. The Futuristic 33, pp. 23-24. 
[18] Frank, V. E. (1963). Man's search for meaning. New York: Pocket Books.

[19] Garrett, G. (2000).The causes of Globalization. Comparative Political Studies 33, pp. 941-991.

[20] Gasper, D. (2003). Human Well-Being: Concepts and Conceptualizations. Dicapai pada Januari 25,2011 dari http://cfs.unipv.it/sen/papers/Gasper.pdf Government of India (2010). Economic Survey. New Delhi: Jain Publications.

[21] Gibson, K., Cahill, A., \& McKay, D. (2010). Rethinking The Dynamics Of Rural Transformation: Performing Different Development Pathways In A Philippine Municipality. Transactions of the Institute of British Geographers, 35, pp. 237-255.

[22] Hammond, A., Adriannse, A., Rodenburg, E., Bryant, D. \& Woodward, R. (1995). Environmental Indicators: A Systematic Approach to Measuring and Reporting on Environmental Policy Performance in the Context of Sustainable Development. Dicapai pada Julai 29, 2012 dari http://pdf.wri.org/environmentalindicators_bw.pdf

[23] Herdenson, H. (1996). What's Next in the Great Debate About Measuring Wealth and Progress?. Challenge 11, pp. 50-56.

[24] Huang P. H. \& Zhan, S. (2009). Migrants Worker's Remittance and Rural Development in China. Dicapai pada Jun 1, 2011 dari http://essays.ssrcorg/acrossborders/wpcontent/uploads/2009/08/ch10.pdf.

[25] Human Resources and Skills Development Canada (2011). Indicators of Well-Being in Canada. Dicapai pada Julai 28, 2011 dari http://www4.hrsdc.gc.ca/h. 4m.2@-eng.jsp.

[26] Ibrahim, Y. (2009). Komuniti Pembangunan dan Transformasi. Bangi. Penerbit Universiti Kebangsaan Malaysia.

[27] Kelles, A. V. (2005). New Challenges and Opportunities for Rural Development. Dicapai pada Jun 15, 2012 dari http://www.ifad.org/innovation/presentations/newopp.pdf

[28] Li, L. (2006). Quality of life as a social reprensentation in China: A qualitative study. Social Indicators Research, 75(2), pp. $217-$ 240.

[29] McGillivray, M (2007). Human Well-Being: Issues, Concepts and Measures. Dicapai pada Oktober 26, 2011 dari http://www.rrojasdatabank.info/humanwellbeing.pdfl.

[30] Md. Nor, N. (2000). Petunjuk Bandar Sebagai Alat Penerapan Konsep Mapan Dalam Pengurusan Dan Pembangunan Bandar Di Malaysia. Prosiding National Seminar: Enviromental Managemant Issues and Challenges in Malaysia.

[31] Midgley, J. (1995): Social Development: The Developmental Perspective In Social Welfare. London: SAGE Publications Ltd.

[32] Nelson, P. B. (2001). Rural Restructuring In The American West: Land Use, Family And Class Discourses. Journal of Rural Studies, 17 , pp. $395-407$.

[33] Nieboer, A., Lindenberg, S., Boomsma, A. \& Van Bruggen, A.C., (2005). Dimensions of well-being and their measurement: The spf-II scale. Social Indicators Research, 73(3), pp. 313-353.

[34] Nyahoho, E. (2001). Globalization And Economic Goals. The Journal of Social, Political, and Economic Studies 26, pp.543-568.

[35] Ouyyanont, P. (2000). Transformation Of Bangkok And Concomitant Changes In Urban-Rural Interaction In Thailand In The 19th $\begin{array}{llllll}\text { And 20th } & \text { Centuries. } & \text { Dicapai } & \text { pada } & & \\ \end{array}$ http://std.cpc.ku.ac.th/delta/conf/Acrobat/Papers_Eng/Volume\%202/Porphan.pdf

[36] Paola Jirón \& Giulietta Fadda (1999). The Process of Formulating Quality of Life Indicators Using a Gender Perspective. The Need for "Gendered" Indicators in Urban Policy, Programme and Project Analysis. Dicapai pada Julai 6, 2012 dari http://www.calidaddevida.uchile.cl/pdf/ Process.pdf

[37] Pollnac, R. B., Pomeroy, R.S., \& Harkes, I.H.T. (2001). Fishery Policy And Job Satisfaction In Three Southeast Asian Fisheries. Ocean and Coastal Management 44, pp. 531-544.

[38] Richardson, H. W. (1973). Regional Growth Theory. London: MacMillan.

[39] Segupta, R., Dipankor, C. \& Bhisma, R. (2007). Impact of a Highway on the Socio-economic Well-being of Rural Households Living in Proximity. Dicapai pada November 22, 2011 dari journal.ciiss.net/index.php/ciiss/article/download /47/41.

[40] Sofer, M., \& Applebaum, L. (2006). The Rural Space In Israel In Search Of Renewed Identity: The Case Of The Moshav. Journal of Rural Studies, 22, ms. 323-336

[41] Su, S. L., Jiang, Z. L., Zhang, Q., \& Zhang, Y. (2011). Transformation Of Agricultural Landscapes Under Rapid Urbanization: A Threat To Sustainability In Hang-Jia-Hu Region, China. Applied Geography, 31, pp. 439-449.

[42] Unit Perancang Ekonomi (1999). Laporan Kualiti Hidup Malaysia 1999. Jabatan Perdana Menteri. Dicapai pada Oktober 1, 2010 dari http://202.75.7.57/New\%20Folder/publication/mqli99/All.pdf.

[43] Yusof, R. (1999). Suatu Penelitian Teoritikal Dari Perspektif Sosial Terhadap Pengertian Konsep Kualiti Hidup. Jurnal Pembangunan Sosial, 1(1), pp. 103-119.

[44] Zakaria, R. (2007). Sustainable Housing For Residential-Industrial Neighbourhoods In Malaysia: A Study On The Element Of Indoor Environmental Quality Improvement. Queensland University of Technology, Queensland. Ph.D. Thesis. 